UDC $78.01+78.03+782$

Kaznacheieva Tetiana,

$\mathrm{PhD}$ in Arts, assistant professor

The Department of Common and Specialized Piano

A. V. Nezhdanova Odessa State Musical Academy

itaniamusic@gmail.com

ORCID 0000-0002-8692-2844

\title{
THE WALTZ GENRE IN THE XIX CENTURY OPERA: THE REALIZATION OF VARIOUS DRAMATURGICAL FUNCTIONS
}

The purpose of the article is consideration of specific features of the embodiment of the waltz genre and its various dramaturgical functions in the nineteenth-century opera. In connection with the statement of this problem, examples of the interpretation of waltz in the classical examples of operatic art in the history of the Ukrainian opera belonging to the specified period are analyzed. The methodology of the research is based on the application of the system-structural, historical and analytical methods, which made it possible to identify innovative methods of interpreting the waltz genre in opera, along with the traditional ones. The scientific novelty consists in considering the waltz as an internal genre element that significantly influences the dramatic art of the opera, and thus opens up the possibility of a new understanding of the integral dramatic art of the opera work. Conclusions. Contributing to the plot and conflict development, often contrasting with the dramatic action, the waltz genre in the XIX century opera transforms its artistic and figurative content. Realizing various dramatic functions, it creates a certain emotional background, models a certain social, domestic and national environment, space and time. Moreover, being an expressive means of imaginative characteristics, the waltz genre contributes to revealing the inner world of the characters, and can also perform the culminating function in the parts of the opera work. The expressive capabilities of the waltz retain their relevance, influencing the viewer's perception in the works of the modern opera theater.

Keywords: the waltz, dance genre, ball, opera, dramaturgical functions.

Казначеєва Тетяна Олександрівна, кандидат мистецтвознав̈н
фортепіано Одеської національної музичної академії ім. А. В. Нежданової

Жанр вальсу в опері XIX століття: реалізація різних драматургічних функцій

Мета статті. Розгляд специфічних особливостей втілення жанру вальсу і його різних драматургічних функцій в опері XIX століття. У зв'язку з постановкою даної проблеми проаналізовані приклади трактування вальсу в класичних зразках оперного мистецтва, в історії української опери, що належать до вказаного періоду. Методологія дослідження ґрунтується на застосуванні системно-структурного, історичного і аналітичного методів, що дозволили виявити, поряд з традиційними, й новаторські прийоми інтерпретації жанру вальсу в опері. Наукова новизна полягає в розгляді вальсу як внутрішнього жанрового елемента, що суттєво впливає на драматургію опери, i, таким чином, відкриває можливості нового розуміння цілісної драматургії оперного твору. Висновки. Сприяючи сюжетному і конфліктному розвитку, нерідко контрастуючи з драматичною дією, жанр вальсу в опері XIX століття трансформує їі художньо-образний зміст. Реалізуючи різні драматургічні функції, він створює певний емоційний фон, моделює певне соціально-побутове, національне середовище, простір, час. Крім того, як виразний засіб образної характеристики, жанр вальсу сприяє розкриттю внутрішнього світу героїв, а також може виконувати кульмінаційну функцію в розділах оперного твору. Виразні можливості вальсу зберігають свою актуальність, впливаючи на сприйняття глядача і в творах сучасного оперного театру.

Ключові слова: вальс, танцювальний жанр, бал, опера, драматургічні функції.

Казначеева Татьяна Александровна, кандидат искусствоведения, и. о. доцента кафредры общего и специализированного фортепиано Одесской национальной музыкальной академии им. А. В. Неждановой

Жанр вальса в опере XIX века: реализация различных драматургических фуннкций

Цель статьи. Рассмотрение специфических особенностей воплощения жанра вальса и его различных драматургических функций в опере XIX века. В связи с постановкой данной проблемы проанализированы примеры трактовки вальса в классических образцах оперного искусства, в истории украинской оперы, принадлежащих к указанному периоду. Методология исследования основывается на применении системно-структурного, исторического и аналитического методов, позволивших выявить, наряду с традиционными, и новаторские приемы интерпретации жанра вальса в опере. Научная новизна заключается в рассмотрении вальса как внутреннего жанрового элемента, существенно влияющего на драматургию оперы, и, таким образом, открывающего возможности нового понимания целостной драматургии оперного произведения. Выводы. Способствуя сюжетному и конфликтному развитию, нередко контрастируя с драматическим действием, жанр вальса в опере XIX века трансформирует ее художественно-образное содержание. Реализуя различные драматургические функции, создает определенный эмоциональный фон, моделирует определенную социально-бытовую, национальную среду, пространство, время. Кроме того, являясь выразительным средством образной характеристики, жанр вальса способствует раскрытию внутреннего мира героев, а также может выполнять кульминационную функцию в разделах оперного произведения. Выразительные возможности вальса сохраняют свою актуальность, влияя на восприятие зрителя и в произведениях современного оперного театра.

Ключевые слова: вальс, танцевальный жанр, бал, опера, драматургические функции.

Relevance of the research theme. For more than two centuries, the waltz remains one of the most famous symbols of European dance culture. Every year more than four hundred and fifty balls take place in Vienna - the city of waltzes. The Viennese ball season officially opens with a waltz, performed in the city center. In February 2019, the legendary Opera Ball, dedicated to the one and a half century anniversary of the Vienna State Opera, took place. Waltz "On the Beautiful Blue Danube" by I. Strauss always remains an obligatory item of its program, as well as an organic part of the ball of the Vienna Philharmonic Society, concerts of the Vienna Philharmonic Orchestra. The waltz is one of the main components of European program of ballroom dancing or Standard. 
Characteristic features of the performance of the waltz as an integral part of everyday dance and ballroom culture of the XIX century are examined in the works on the theory and history of dance art by L. Blok, A. Vaganova, M. Vasilyeva-Rozhdestvenskaya, A. Volynsky, N. Gavlikovsky, N. Ivanovsky, V. Mikhnevich.

A detailed recreation of the traditions of Pushkin's balls, a description of the movements of various types of the waltz, illustrations and musical examples make up the contents of the collection by N. Entelis [5].

A ballroom dancing as a phenomenon of the culture of romanticism in the artistic biography of M. Glinka and the specificity of certain dance genres (including waltz) were analyzed by A. Gadetskaya [2].

The cultural significance of the overall popularity of the waltz in the first half of the XIX century, its embodiment in the works of J. Lanner, I. Strauss Sr. and F. Schubert are analyzed by J. Simpson-Candelaria [10].

The transformations of the Victorian waltz into the modern English waltz of the early 1920s, its adaptation to the modern English ballroom, as well as the role of club and national competitions in changing and preserving the shape and style of the waltz, are studied in the articles of T. Buckland [6; 7].

At the same time, the problem of the realization of the waltz genre in the opera has been hardly explored in the musicological literature. Quite often, the waltz is found in classical examples of the opera art. In the works of the modern opera theatre, the artistic and imaginative waltz content is transformed, that indicates that composers remain interested in the expressive capabilities of this genre [11].

The purpose of the study is to consider the specific features of the embodiment of the waltz genre and its various dramaturgical functions in the nineteenth-century opera.

The statement of the basic material. The origin of the name of the dance - waltz (German - Walzer, French - Valse, English - Waltz, Italian - Valsero) is associated with the German word walzen - rotation of something with the movement of a rotating object. One of the meanings of this word is also to whirl, slide. With reference to Grove dictionary, the origin of the waltz is shrouded in even more uncertainty than usually in the case with the most famous dances $[8,431]$. The tremendous popularity, which it achieved in the XIX century, gave rise to a debate about the historical origin of the waltz.

Some researchers associate the origins of the dance with either the allemande or the volta. An opinion of F. Klingenbek - an author of the book "The Immortal Waltz" ("Unsterblicher Walzer") is quite interesting. He believed that the rhythms of the waltz were found in ancient folk songs, and thus, most likely, they later appeared into the repertoire of the Minnesingers [1, p. 177]. Couplets of this kind of dance songs were remarkable for a lively rhythm and ease. According to other researchers (K. Mleinek, J. Simpson-Candelaria, M. VasilyevaRozhdestvenskaya), the origin of the dance is connected with the traditions of the Austrian dance - the Ländler. In this aspect, traditions of simple tavern and outdoor entertainment are transformed in the waltz genre. The subsequent admission of the waltz into the higher classes of society is also noted [10].

There is a significant number of varieties of the waltz, with the characteristic features of performance and composition.

The slow waltz is distinguished by its smooth, plastic pendulous movements. The musical accompaniment follows at a slow tempo and is characterized by a pronounced melody. The Boston Waltz is an American version of a dance with wide, long steps and deep descents.

The Viennese, moderately quick waltz, which is also called Pas Valse, is characterized by a more agile tempo, the circle rotation of partners, gliding movements and quick, sharp head turns.

There are different types of the waltz, such as the allemande (valse a trios - waltz in three) - performed by two ladies and one partner; the minion - smooth and reserved; the figure waltz; Valse à Deux Temps and others.

The main waltz movements are waltz walk; waltz turns, pas Balancé, pas Glissé. Musical time is 3/4, 6/8. The tempo depends on the type of the waltz (from slow to moderately fast, agile).

The pattern of the dance is based on couple movement in a circle. The circular movement determined the musical content of the works accompanying the dance. It is characterized by a clear, square structure, the sequential principle of development, a bright focus on the first beat of the measure and a certain rhythmic formula.

Let us turn to certain aspects of the embodiment of the waltz genre in various works representing the operatic tradition.

The initial version of the waltz appeared in Vienna at the end of the XVIII century. It was during this period that the waltz became a part of an opera performance for the first time.

In the comic opera of the Spanish composer Martin-y-Soler "Una cosa rara, ossia Bellezza ed onestà" ("A rare thing, or beauty and honesty") libretto by Lorenzo da Ponte based on a play by L. Veles de Guevara, which premiered on November 17, 1786 in Vienna Burgtheater, four girls dance to the waltz music in the finale of the second act. The melody of the female quartet, which was sustained in the near-waltz movement, became very popular [3, p. 134].

The opera "La Traviata" by G. Verdi becomes the symbolic embodiment of the diverse expressive capabilities of the waltz during its flourishing in the XIX century. In this work, the genres of everyday dance music (the gallop, the waltz, etc.) create a background with which a certain social and domestic, national environment, space, and time are modeled. The composer uses the genre signs of the waltz especially widely. Deep insight into their essence helps the composer to form a complete drama of the work. Melodies and rhythms of the waltz are the unique color that has become an organic part of the score. In many respects, it was precisely due to the 
different figurative interpretations of several types of the waltz (slow, Viennese, quick) that opera gained such wide popularity.

In the XIX century, the waltz, in accordance with the accepted requirements of the etiquette and the program, became the main dance of the ball, its center, not only in the noble salons of Western Europe. As $\mathrm{N}$. Entelis notes, the ballroom culture of Pushkin's time gave rise to the poeticization of the waltz; Russian lyrical waltz entered European culture together with the Viennese or Parisian [5, p. 17].

M. Glinka, who possessed practical knowledge of the dance subtleties of the waltz, was an outstanding expert in ballroom culture. The composer lived in the era when all "components of the ballroom ceremonial, on one hand, became established and acquired a "classic" look, and on the other hand, - when numerous elements of the ball as a complicated social complex were transformed and symbolically reconsidered, reflecting the processes existing in social life" [2, p. 15-16].

In the second act of the opera "Ivan Susanin" M. Glinka creates a bright, expressive, rich ball scene, which is essential for the drama of the opera as a whole. The basis of the opera is known for dramatic contrast, opposition, intonational conflict between the Russian and Polish camps. A variety of dance genres is used as a characteristic of action patterns and counter-actions.

The waltz in the opera "Ivan Susanin" (Allegro moderato, A-dur, noted as "dancing"), created by M. Glinka, as a dance genre contributes to the formation of the image of the Poles. It performs an important dramatic function, characterizing the counter-action. In the sequence of dance orchestral items, the waltz is after Krakowiak, and by common order of the dances in the opera - in the center of a large dance form - there is a collection of "separate dance episodes distributed throughout the opera, more or less decorated, but connected by a single principle of dramatic development" [9, p. 169]. The main theme adjusts to the characteristic waltz rhythm (6/8), gives the whole item a single complete image, associating in the imagination with the atmosphere of the society life of the higher class of Polish society.

A similar function - the formation of the image of a counter-action - is performed by the waltz in the opera "The Siege of Dubno" by P. Sokalsky, the first of Ukrainian composers, who turned to the plot of N. Gogol's story "Taras Bulba". The internal state of Ursula, daughter of the Kiev governor, was rendered in arioso (№4) using the tempo and rhythm of the waltz. Various rhythmic sequences create a light, dancing image, being an expressive means of imaginative characteristics.

The tendency of contraposition of two contrasting musical images: Ukrainian and Polish, found in the work "Ivan Susanin" by M. Glinka and continued by P. Sokalsky ("Siege of Dubno"), is also developed in monumental historical and heroic opera "Taras Bulba" by N. Lysenko - summit of the composer's professional skill.

The plot of the dramatic conflict creates musical contraposition of two contrasting dance images. The Polish image is formed due to the use of typical dance means in the orchestral part: dotted leitrhythm, mazurka genre and waltz movement (in creating the lyric image of the governor's daughter). In the second scene, with the appearance of the daughter of the Polish governor, the dotted leitrhythm was used in the accompaniment melody. Then Maryltsya sings a carefree arietta in the form of mazurka "I was born in the chambers". The episode of the meeting with Andriy is based on the waltz movement. The dance genre subtly conveys the beginning of the development of romantic relationships between the characters.

An interpretation of the waltz genre in the opera "Eneida" by N. Lysenko is quite interesting. In the second act, the waltz is an integral part of the suite dance form - a through construction consisting of a series of polygenre dances, which can be connected by a leitmotif, leitrythm, leit-harmony, and leit-intonation [4, p. 135]. After the Dance of the Graces (№14, Andantino grazioso) and the hopak on Olympus (№15), the waltz (№16) follows.

A novelty in interpreting the waltz genre in opera is the manifestation of its culminating function in the finale of the second act (quintet). After the central satirical scene of the opera (the feast of the gods on the top of Olympus) the final part follows, in the orchestral accompaniment of which the genre features of the Boston waltz are distinguished (6/8, "Little Bird flies"). This is manifested in the dominance of the melodic beginning, free agogic changes in tempo.

Conclusions. Thus, the genesis of the genre features of the waltz and an analysis of its influence on the formation of the multi-faceted integrity of the opera makes it possible to note the uniqueness of this dance genre. Contributing to the plot and conflict development, often contrasting with the dramatic action, the waltz genre in the nineteenth-century opera transforms its artistic and figurative content. Realizing various dramaturgical functions, it creates a certain emotional background, models a certain social, domestic and national environment, space and time. In addition, being an expressive means of imaginative characteristics, the waltz genre contributes to the disclosure of the inner world of the characters, and can also perform the culminating function in the parts of the opera work.

The expressive capabilities of the waltz retain their influence on the viewer's perception in such masterpieces of the world opera as "Eugene Onegin" by P. Tchaikovsky, "La Boheme" by J. Puccini, "War and Peace" by S. Prokofiev, "The Knight of Roses" by R. Strauss, etc. In the works of the modern opera theatre, the models of its dramatic functions are transformed, but the waltz remains relevant, being a symbolic genre of the dance era of the XIX century. 


\section{תimepamypa}

1.Васильева-Рождественская М. В. Историко-бытовой танец: Учеб. Пособие. 2-е изд., пересмотр. Москва: Искусство, 1987. 382 c.

2. Гадецька Г. М. Бальні танці як явище культури романтизму в творчій біографії М. І. Глінки : автореф. дис. на здобуття наук. ступеня канд. мистецтвознавства: 26.00.01. Київ, 2011. 20 с.

3. Єфанова С. О. До питання еволюції вальсу як різновиду бального танцю: історико-мистецтвознавчий аналіз. Вісник Національної академії керівних кадрів культури і мистецтв. 2017. № 2. С. 132-136.

4. Казначеєва Т. О. Феномен українського національного танцю в опері М. Лисенка «Енеїда». Міжнародний вісник: культурологія, фрілологія, музикознавство. Київ: Міленіум, 2017. Вип. I (8). С. 133-139.

5. Энтелис Н. Л. Пушкинский бал с описанием традиций и подлинными танцами. Санкт-Петербург: Композитор-СанктПетербург, 1999. 55 с.

6. Buckland, T. (2018). How the Waltz was Won: Transmutations and the Acquisition of Style in Early English Modern Ballroom Dancing. Part One: Waltzing Under Attack. Dance Research. 36. 1-32.

7. Buckland, T. (2018). How the Waltz was Won: Transmutations and the Acquisition of Style in Early English Modern Ballroom Dancing. Part Two: The Waltz Regained. Dance Research. 36. 138-172.

8. Grove G. Dictionary of Music and Musicians: in five volumes. New York-London: MACMILLAN \& Co., Ltd. Vol. V. 1910. 745 p.

9. Kaznacheieva, T. National trends in the dance genres of polish and Czech opera of the period of the national school development. Вісник Національної академії керівних кадрів культури і мистецтва: наук. журнал. К.: Міленіум, 2017. №4. С. $168-171$.

10. Simpson-Candelaria J. The waltz: its pervasiveness in the first half of the nineteenth century, and its transformation into a symbol of the Biedermeierzeit in the works of Joseph Lanner, Johann Strauss, and Franz Schubert. Published by the M. A. University of British Columbia, 1982. 129 p.

11. Snelson J. Waltzing down the years: the powerful symbolism of Vienna's defining dance URL: https://www.roh.org.uk/news/waltzing-down-the-years-the-powerful-symbolism-viennas-defining-dance.

\section{References}

1.Vasileva-Rozhdestvenskaya, M. V. (1987). Historical and household Dance: tutorial. Moscow: Iskusstvo [in Russian].

2.Gadetska, G. M. (2013). Ballroom dancing as a cultural phenomenon of romanticism in the creative biography of Mikhail Glinka. Extended abstract of candidate's thesis. Kyiv [in Ukrainian].

3.Efanova, S. O. (2017). On the issue of the evolution of the waltz as a kind of ballroom dance: historical and artistic analysis. Bulletin of the National Academy of Cultural and Arts Management, 2, 132-136 [in Ukrainian].

4. Kaznacheieva, T. O. (2017). The phenomenon of Ukrainian national dance in the opera of M. Lysenko «Eneida». International Bulletin: Culturology, Philology, Musicology, Kyiv. Iss. I (8), 133-139 [in Ukrainian].

5.Entelis, N. L. (1999). Pushkin Ball with a description of traditions and authentic dances. St. Petersburg: Kompozitor SanktPeterburg [in Russian].

6.Buckland, T. (2018). How the Waltz was Won: Transmutations and the Acquisition of Style in Early English Modern Ballroom Dancing. Part Two: The Waltz Regained. Dance Research. 36. 138-172 [in English].

7.Buckland, T. (2018). How the Waltz was Won: Transmutations and the Acquisition of Style in Early English Modern Ballroom Dancing. Part One: Waltzing Under Attack. Dance Research. 36. 1-32 [in English]. English].

8.Grove, G. (1910). Dictionary of Music and Musicians: in five volumes. Vol. V. New York-London: MACMILLAN \& Co., Ltd. [in

9.Kaznacheieva, T. (2017). National trends in the dance genres of polish and Czech opera of the period of the national school development. Bulletin of the National Academy of Cultural and Arts Leaders, 4, 168-171 [in English].

10. Simpson-Candelaria, J. (1982). The waltz: its pervasiveness in the first half of the nineteenth century, and its transformation into a symbol of the Biedermeierzeit in the works of Joseph Lanner, Johann Strauss, and Franz Schubert. Published by the M. A. University of British Columbia [in English].

11. Snelson, J. Waltzing down the years: the powerful symbolism of Vienna's defining dance. Retrieved from: https://www.roh.org.uk/news/waltzing-down-the-years-the-powerful-symbolism-viennas-defining-dance [in English]. 